\title{
Spatial Satisfaction and Expectation Analysis of University Campus Users, Case Study of Yozgat Bozok University
}

\author{
Secil Gul Meydan Yildiz (Corresponding author) \\ Department of City and Regional Planning, Yozgat Bozok University, Yozgat, Turkey \\ ORCID: https://orcid.org/0000-0001-9869-4159 \\ E-mail: secil.meydan@bozok.edu.tr \\ Ilker Atmaca \\ Department of City and Regional Planning, Yozgat Bozok University Yozgat, Turkey \\ E-mail: ilker.atmaca@bozok.edu.tr \\ Muhammed Ozgur Oguz \\ Department of City and Regional Planning, Yozgat Bozok University, Yozgat, Turkey \\ E-mail: ozgur.oguz@bozok.edu.tr
}

\begin{abstract}
University campuses are dynamic spaces where the social and physical environment integrates with natural and artificial landscape elements and requires continuous change and development. The intellectual working environment, which guides both the scientific, technical and technological developments of the age as well as the socialization, entertainment and recreation activities, is named the university campus. Therefore, it is very significant that planning of university campuses, with a holistic design approach that appeals to all users such as students, academicians, administrative staff and visitors when considered these places where all kinds of technical, practical and cultural information are shared and produced.

The main objective of this study, titled "Spatial Satisfaction and Expectation Analysis of University Campus Users, Case Study of Yozgat Bozok University", is to measure and evaluate the social and physical satisfaction and expectation levels of the students, academic and administrative staff of the university campus with face to face survey technique. Erdoğan Akdağ Campus is the central settlement of Yozgat Bozok University. Situated $8 \mathrm{~km}$ from Yozgat city center, the campus is built on an area of approximately 391 hectares. There are 12 academic education buildings in the campus area and 12 service buildings and artificial-natural landscaping items to meet various needs of the campus users. In the formation of the campus area, the demands and expectations of the users have a guiding feature. Therefore, this study, which is composed of approximately 12000 students, 500 academic and 250 administrative staff, will provide the necessary criteria / indicators in the future development of the settlement area in the spatial context. In this project, the settling characteristics of spatial trends/preferences and differentiated behavior patterns unique to the settlement, and parameters regarding how these will be evaluated in planning process, will be put forward.
\end{abstract}

Keywords: Campus Design, Spatial Satisfaction, Spatial Expectation, Yozgat Bozok University.

DOI: $10.7176 / \mathrm{JSTR} / 5-2-30$

\section{Üniversite Yerleşkesi Kullanıcılarının Mekânsal Memnuniyet ve Beklenti Analizi, Yozgat Bozok Üniversitesi Örneği}

\begin{abstract}
Özet
Üniversite yerleşkeleri sosyal ve fiziksel çevrenin doğal ve yapay peyzaj öğeleriyle bütünleştiği, sürekli değişime ve gelişime gereksinim duyan dinamik mekânlardır. Hem çağın bilimsel, teknik ve teknolojik gelişmelerine yön veren, hem de sosyalleşme, eğlenme ve dinlenme faaliyetlerinin gerçekleşmesine olanak sunan entelektüel çalı̧̧ma ortamına üniversite yerleşkesi adı verilmektedir. Dolayısıyla teknik, pratik ve kültürel her türlü bilginin paylaşıldığg ve üretildiği üniversite yerleşkelerinin öğrenci,
\end{abstract}


akademisyen, idari personel ve ziyaretçi gibi tüm kullanıcılara hitap eden bir tasarım anlayışıyla bütüncül olarak planlanması çok önemlidir.

"Üniversite Yerleşkesi Kullanıcılarının Mekansal Memnuniyet ve Beklenti Analizi, Yozgat Bozok Üniversitesi Örneğì” başlıklı bu çalışmanın temel amacı, üniversite yerleşkesi kullanıcılarını oluşturan öğrenciler ile akademik ve idari personelin sosyal ve fiziksel memnuniyet ve beklenti düzeylerini yüz yüze anket tekniğiyle ölçmek ve değerlendirmektir. Yozgat Bozok Üniversitesi'nin merkez yerleşkesini Erdoğan Akdağ Yerleşkesi oluşturmaktadır. Yozgat kent merkezine $8 \mathrm{~km}$ mesafede yer alan yerleşke, yaklaşık 391 hektarlık bir alanın üzerine kurulmuştur. Yerleşke alanı içinde 12 adet akademik eğitim binası ve yerleşke kullanıcılarının çeşitli ihtiyaçlarını karşılamaya yönelik 12 adet hizmet binası ile yapay-doğal peyzaj öğeleri bulunmaktadır. Yerleşke alanının şekillenmesinde kullanıcıların talep ve beklentileri yol gösterici niteliktedir. Dolayısıyla evrenini, yaklaşık 12000 öğrenci, 500 akademik ve 250 idari personelin oluşturduğu bu çalışma, gelecekte yerleşke alanının mekansal bağlamda geliştirilmesi aşamasında gerekli ölçütlerin/göstergelerin ortaya konulmasını sağlayacaktır. Bu projede, mekansal eğilimler/tercihler ve yerleşkeye özgü farklılaşan davranış biçimlerinin ve yaşam çevrelerinin oluşturulması açısından belirleyici özellikler ve bunların planlama süreçlerinde nasıl değerlendirileceğine ilişkin parametreler ortaya konulacaktır.

Anahtar Kelimeler: Yerleşke Tasarımı, Mekansal Memnuniyet, Mekansal Beklenti, Yozgat Bozok Üniversitesi.

\section{Giris}

Bir üniversitenin kalitesi, eğitim sisteminin bir ürünü olarak nitelendirilebilecek eğitimli insan kaynağının farklı sektörlerde, dolayısıyla kalkınmada etkin rol oynayabilme derecesi ile doğru orantılıdır. Beşeri sermaye ile mekan kalitesi arasındaki ilişki, gerek sosyal altyapı, gerekse fiziksel altyapı olarak geniş kapsamlı biçimde değerlendirilip, algı ve beklentilerin doğru biçimde incelenmesi, yorumlanması ve ihtiyaç duyulan müdahalelerin vaktinde ve etkin biçimde gerçekleştirilmesi ile sağlanabilmektedir.

Üniversite yerleşke alanları, dar anlamıyla kullanıcıların kültürel, eğitsel, sosyal ve sanatsal bilgi birikimlerini paylaştığı, aktardığı, tekrar öğrendiği mekan parçalarıdır. Bu mekan parçalarının kalitelerinin temelinde hem nesnel gerçekliği ifade eden sosyo-kültürel çevrenin yaşam standartları hem de bireyin öznel algılama düzeyini ve kimliğini yansıtan belirli ya da belirsiz içsel standartlar ve yaşam anlayışı yer almaktadır (Geray, 2018: 285; Kabadayı, 2006).

Yerleşke alanı içindeki yapıların birbirleriyle ve diğer öğelerle olan ilişkileri mekanın kalitesini ve yaşanılabilirliğini etkilemektedir (İnceoğlu ve Aytuğ, 2009: 132). Gereksinimlere yanıt veren mekanlar, kullanıcıların istek ve kullanımlarına hizmet edebilen mekanlardır (Tekeli vd., 2004). Kamusal mekanlar kapsamında yer alan üniversite yerleşke alanları için öncelikli gereksinimler rahatlık, dinlenme, aktif/pasif katılım, keşfetme ve diğer öğeler şeklinde sınıflandırılmaktadır (İnceoğlu ve Aytuğ, 2009: 133; Aydıner Boylu ve Paçacioğlu, 2016: 144). Bu öğelerin belirlenen ölçütlerin üzerinde nitelik taşıması yaşam kalitesinin iyi düzeyde olduğunu göstermektedir (Okumuş ve Eyüpoğlu, 2015). Üniversite mekanının sunduğu olanak ve firsatlardan bireylerin eşit, dengeli ve gereksinimleri oranında yararlanması, aynı zamanda eğitsel, sanatsal, kültürel etkinliklere etkin biçimde katılabilme olanaklarına sahip olabilmesi yerleşke alanının yaşanılabilirliğini belirleyen ilkelerdir. Yerleşke alanının yaşanılabilirliğinin ölçülmesinde ulaşılabilirlik, eşitlik, adil olma ve katılım gibi hakların da dikkate alınması gereklidir (Kayır, 2007: 562).

\subsection{Araştırmanın Amacı ve Yöntemi}

"Üniversite Yerleşkesi Kullanıcılarının Mekansal Memnuniyet ve Beklenti Analizi, Yozgat Bozok Üniversitesi Örneği” başlıklı çalışmada, üniversitelerin kalitelerini değerlendirmede fiziksel odaklı bir araç olarak yerleşke alanının ve bu alanın parçaları olan hizmet tesislerinin kullanıcılarda ortaya çıkardığ algılar ve beklentiler arasındaki farkın ölçülmesi amaçlanmaktadır. Mekansal kalite ile kullanıcı memnuniyeti arasındaki ilişkinin ortaya konulması ve yerleşke alanının mekansal kalitesinin kullanıcı memnuniyeti üzerindeki etki derecesi, örneklem alan olarak seçilen Yozgat Bozok Üniversitesi özelinde ortaya konulmaktadır.

Bu çalışmada mekansal kalite, bir mekanın fiziksel, sosyal ve sembolik açıdan kullanıcıyı tatmin etmesi ve mutluluk uyandırması olarak tanımlanmaktadır. Bu süreç, Alkema ve Van der Veen, Evans (1994) tarafindan kurgulanan mekansal kalite sınıflandırmasında (habiforum matrix); kullanım değeri, deneyimleme değeri ve gelecekteki değeri olmak üzere üç temel öğe üzerinden açılanmaktadır (bkz. Tablo 1). 
Tablo 1. Habiforum Mekânsal Kalite Matrisi

\begin{tabular}{|c|c|c|c|c|}
\hline & Ekonomik Çekicilik & Sosyal Çekicilik & Ekolojik Önem & Külttürel Önem \\
\hline $\begin{array}{c}\text { Kullanım } \\
\text { değeri }\end{array}$ & $\begin{array}{l}\text { - Akıllı yer seçimi } \\
\text { - Erişilebilirlik } \\
\text { - Teşvik edicilik } \\
\text { - Karma kullanım }\end{array}$ & $\begin{array}{l}\text { - Erişim İmkânı } \\
\text { - Adil dağıtım } \\
\text { - Katkı } \\
\text { - Seçim } \\
\text { alternatifleri }\end{array}$ & $\begin{array}{l}\text { - Diş güvenlik } \\
\text { - Temiz çevre } \\
\text { - Su dengesi } \\
\text { - Ekolojik yap1 }\end{array}$ & $\begin{array}{l}\text { • Seçim özgürlüğ̈̈ } \\
\text { • Kültürel çeşitlilik }\end{array}$ \\
\hline $\begin{array}{l}\text { Deneyimle } \\
\text { me değeri }\end{array}$ & $\begin{array}{l}\text { • Görüntü/görünüm } \\
\text { • Cazibe }\end{array}$ & $\begin{array}{l}\text { - Denklik } \\
\text { - Bağlant1lilık } \\
\text { - Sosyal Güvenlik }\end{array}$ & $\begin{array}{l}\text { - Barış ve mekân } \\
\text { - Doğal güzellik } \\
\text { - Sağllkl yaşam } \\
\text { ortamı }\end{array}$ & $\begin{array}{l}\text { - Bireysellik } \\
\text { - Kültürel özgünlük } \\
\text { - Kontrast mekân }\end{array}$ \\
\hline $\begin{array}{l}\text { Gelecekteki } \\
\text { değer }\end{array}$ & $\begin{array}{l}\text { - Durağanlık ve } \\
\text { esneklik } \\
\text { - Yığılma } \\
\text { - Cazibe merkezi }\end{array}$ & $\begin{array}{l}\text { - Herkesin } \\
\text { katılımı } \\
\text { - Sosyal destek }\end{array}$ & $\begin{array}{l}\text { - Ekolojik varlık } \\
\text { - Sağlıklı } \\
\text { ekosistemler }\end{array}$ & $\begin{array}{l}\text { - Miras } \\
\text { • Kültürel yenilik } \\
\text { • Bütünleşme }\end{array}$ \\
\hline
\end{tabular}

Kaynak: Evans, 1994; Alkema Y. \& Van der Veen, I. "Methodology for Spatial Quality", (http://www.werkpartners.net/uploads/Gorecht.pdf, 23.01.2019).

Yozgat Bozok Üniversitesi’nin merkez yerleşkesini Erdoğan Akdağ Yerleşkesi oluşturmaktadır. Bu çalışmada Erdoğan Akdağ Yerleşkesi kullanıcılarını oluşturan öğrencilerin, akademik ve idari personelin sosyal ve fiziksel memnuniyet ve beklenti düzeyleri yüz yüze anket tekniği kullanılarak ölçülmektedir. Yerleşke kullanıcıları olarak tanımlanan öğrenci, akademik ve idari personelin istatistiksel bazda incelenecek özellikler bakımından farklılıklar göstermesi sebebiyle anket sayısına temel teşkil eden örneklem tespitinde rassal örneklem yöntemlerinden tabakalı örneklem yöntemi uygulanmıştır.

Örneklem sayısının hesaplanmasında, hata payının ve güven aralığının tespit edilmesi için öncelikli olarak pilot anket uygulaması yapılmıştır. Buna göre örneklem alanı, toplam popülasyonu oluşturan 2017-2018 akademik yılı toplam aktif yerleşke kullanıcı sayısına bağlı olarak, Slovin Formülü ile 730 kişi olarak belirlenmiştir.

Kullanıcı tercihlerine görece yerleşkedeki memnuniyet ve beklentilerin net olarak ortaya konulabilmesi amacıyla, uygulanan anketlerin yerleşke alanındaki konumu ve toplam kullanıcı sayısı temel alınarak bir dağılım sağlanmıştır (bkz. Tablo 2).

Ankete katılan 730 kişinin ankette yer alan bazı soruları daha iyi anlamalarını sağlamak için görünüş geçerliği uygulanmıştır. Anketlerin yanıtlanmasında ve değerlendirilmesinde katılımcıların alg1, tutum veya görüşlerinin hesaplanması için Likert Ölçeği kullanılmıştır. Ölçek $1-5$ aralığında olup, "1" hiç memnun değil, " 2 " memnun değil, " 3 " orta memnun, "4" memnun ve " 5 " çok memnun olarak ifade edilmektedir.

Ankete katılan toplam 730 kişinin tamamı anket sorularının hepsini yanıtlamıştır. Ön değerlendirmelerde eksik ya da yetersiz görülen anketler çalışmaya dahil edilmemiş, eksik anket sayısı kadar yeniden anket yapılmıştır. 
Tablo 2. Uygulanan Anket Sayılarının Birimlere Göre Dağılımı

\begin{tabular}{|c|c|c|c|c|c|c|}
\hline Anket Yapılacak Birim & 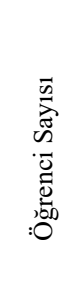 & 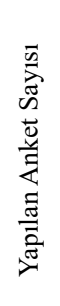 & 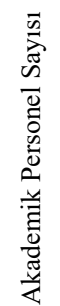 & 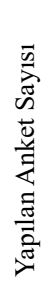 & 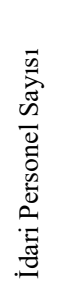 & 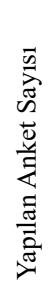 \\
\hline Eğitim Fakültesi & 1238 & 72 & 17 & 1 & 7 & $\mathbf{0}$ \\
\hline Fen Edebiyat Fakültesi & 1994 & 116 & 98 & 6 & 8 & $\mathbf{0}$ \\
\hline İktisadi ve İdari Bilimler Fakültesi & 1364 & 79 & 50 & 3 & 12 & 1 \\
\hline İlahiyat Fakültesi & 1023 & 59 & 34 & 2 & 6 & $\mathbf{0}$ \\
\hline İletişim Fakültesi & 53 & 3 & 15 & 1 & 3 & $\mathbf{0}$ \\
\hline Mühendislik Mimarlık Fakültesi & 2818 & 163 & 88 & 5 & 19 & 1 \\
\hline Tıp Fakültesi & 367 & 21 & 117 & 7 & 8 & $\mathbf{0}$ \\
\hline Ziraat Fakültesi & 73 & 4 & 31 & 2 & 5 & $\mathbf{0}$ \\
\hline Beden Eğitimi Yüksekokulu & 275 & 16 & 17 & 1 & 7 & $\mathbf{0}$ \\
\hline Sağlık Yüksekokulu & 626 & 36 & 24 & 1 & 6 & $\mathbf{0}$ \\
\hline Sağlık Hizmetleri Meslek Yüksekokulu & 817 & 47 & 18 & 1 & 3 & $\mathbf{0}$ \\
\hline Fen Bilimleri Enstitüsü & 618 & 36 & & & 4 & $\mathbf{0}$ \\
\hline Sağlık Bilimleri Enstitüsü & 131 & 8 & & & 2 & $\mathbf{0}$ \\
\hline Sosyal Bilimler Enstitüsü & 432 & 25 & & & 3 & $\mathbf{0}$ \\
\hline Kütüphane & & & & & 14 & 1 \\
\hline Rektörlük & & & & & 146 & 9 \\
\hline TOPLAM & 11829 & 686 & 509 & 30 & 253 & 14 \\
\hline
\end{tabular}

Kaynak: Y.B.Ü. Öğrenci İşleri Daire Başkanlığı, Y.B.Ü. Personel Daire Başkanlığg 1 verilerinden derlenmiştir.

\subsection{Araştırma Alanının Genel Özellikleri}

Yozgat Bozok Üniversitesi 01 Mart 2006 tarihinde 5467 Sayılı Kanunla kurulmuş bir devlet üniversitesidir. Kuruluşu öncesinde Erciyes Üniversitesi (Kayseri) bünyesinde bulunan Fen-Edebiyat Fakültesi, İktisadî ve İdarî Bilimler Fakültesi, Mühendislik-Mimarlık Fakültesi, Ziraat Fakültesi, Sağlık Yüksekokulu ve Meslek Yüksekokulu birimleri, 2006 yılı sonrasında Yozgat Bozok Üniversitesi bünyesine dahil olmuştur. Üniversitenin ana yerleşkesini oluşturan Erdoğan Akdağ Yerleşkesi, Yozgat'ın Merkez ilçesinde, D200 karayolu üzerinde, şehir merkezine $8 \mathrm{~km}$ mesafede bulunmaktadır. 2006 yılında yaklaşık 35 hektarlık bir yapılaşmış alanda toplamda 2573 kullanıcıya (2367 öğrenci, 168 akademik personel, 38 idari personel) hizmet eden yerleşke alanı 2018 yılına gelindiğinde 115 hektarı yapılaşmış olmak üzere toplamda 410 hektarlık bir alana genişlemiş ve bu alanda toplamda 12591 kullanıcıya (11829 öğrenci, 509 akademik personel, 253 idari personel) hizmet etmektedir (bkz. Şekil 1). 


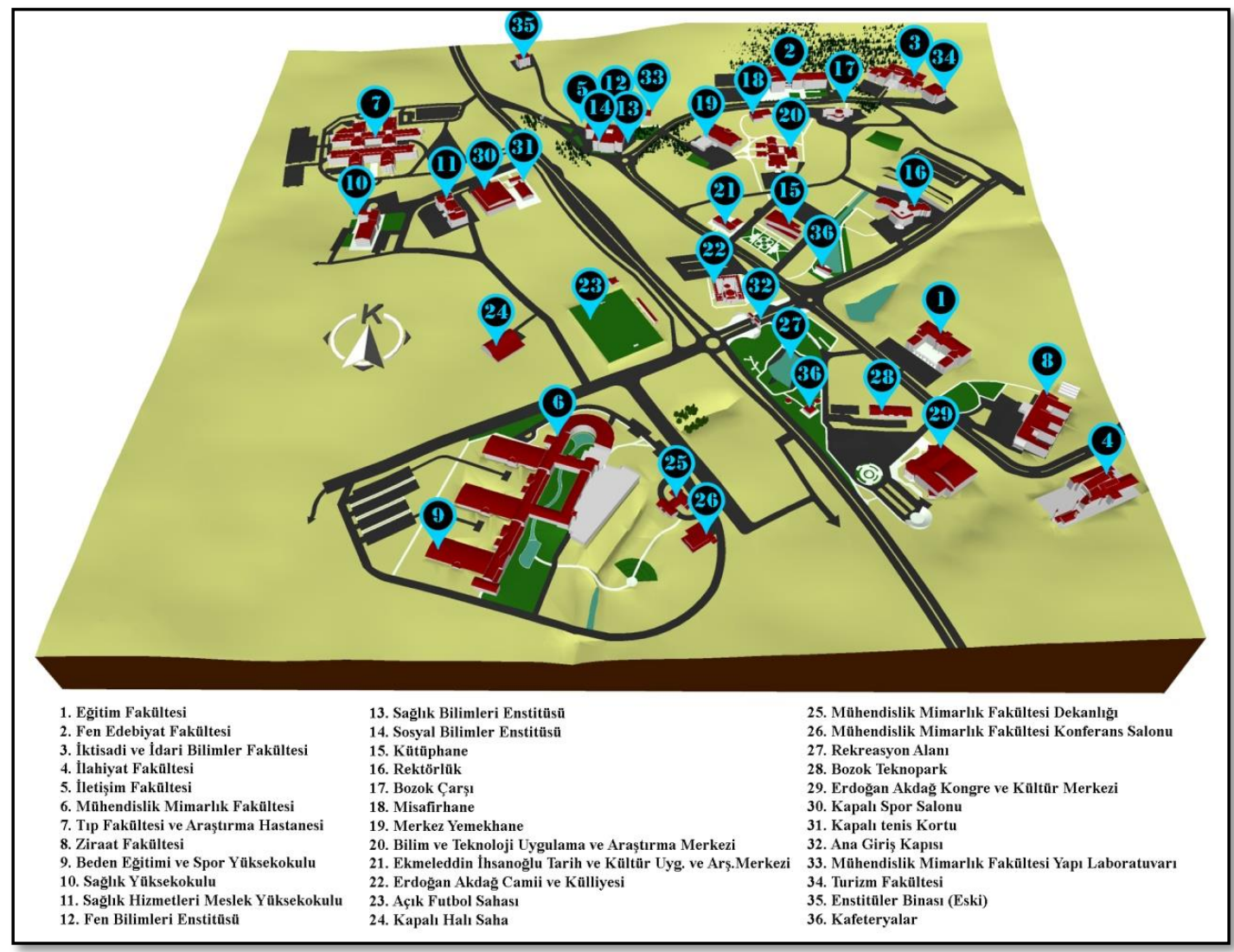

Şekil 1. Yozgat Bozok Üniversitesi Erdoğan Akdağ Yerleşkesi 2018 Y11ı Üç Boyutlu Haritası

Merkez yerleşkede on iki fakülte, üç enstitü, beş yüksekokul, bir meslek yüksekokulu, rektörlüğe bağlı üç bölüm, on altı merkez, Bilim ve Teknoloji Uygulama ve Araştırma Merkezi, Bozok Teknopark, Araştırma ve Uygulama Hastanesi, bir kongre merkezi, iki cami, bir misafirhane ve iki spor salonu bulunmaktadır (Yozgat Bozok Üniversitesi, 2019).

\section{Araştırma Bulguları}

Çalışmanın temelde odaklandığı konu, yerleşke alanının görsel olarak değerlendirilmesinin yanında alanın asıl kullanıcılarının alandaki memnuniyetlerinin ve beklentilerinin ortaya konulmasıdır. Bu bağlamda daha önce bahsedilmiş olan ve memnuniyetin ölçülmesinde bir araç olarak kullanılacak olan, kalite ölçütlerinin kullanıcılarca değerlendirilmesi aşamasında rastgele seçilen toplam 730 kişi ile anket görüşmesi yapılmıştır.

Görüşme yapılan yerleşke kullanıcılarının \% 94'ü öğrenci (686 kişi), \% 4.1'i akademik personel (30 kişi) ve \% 1.9'u idari personel (14 kişi) olup bunların \% 48.9 'u erkek, \% 51.1'i kadındır. Görüşme yapılan kullanıcıların yaş gruplarına dağılımı incelendiğinde 18-24 yaş arasında 648 kişi, 25-34 yaş aralığında 52 kişi, 35-44 yaş aralığında 26 kişi ve 45-54 yaş aralığında 4 kişi olarak dağılım gösterdiği ile 55 yaş ve üstü kullanıcıların ankette yer almadığı gözlenmektedir. Görüşme yapılan kullanıcıların \% 39,2'si yerleşke içinde yer alan yurtlarda, \% 21,9'u yerleşme dişındaki yurtlarda, \% 0,13'ü konuk evinde, \% 38,5'i öğrenci evi, aile konutu gibi evlerde ve \% 0,27'si özel yurt, polis evi, lojman, öğretmenevi vb. alanlarda yaşayanlardan oluşmaktadır. 
Tablo 3. Anket Görüşmesine Katılan Kullanıcıların Özelliklerine Göre Dağılımı

\begin{tabular}{|c|c|c|c|}
\hline \multicolumn{2}{|c|}{ Özellik Türü } & \multirow{2}{*}{$\begin{array}{c}\text { Kişi Sayısı } \\
686\end{array}$} & \multirow{2}{*}{$\begin{array}{c}\begin{array}{c}\text { Toplamdaki } \\
\text { Payı }\end{array} \\
94 \%\end{array}$} \\
\hline \multirow{3}{*}{$\begin{array}{c}\text { Kullanıcı } \\
\text { Türü }\end{array}$} & Öğrenci & & \\
\hline & Akademik Personel & 30 & $4.1 \%$ \\
\hline & İdari Personel & 14 & $1.9 \%$ \\
\hline \multirow{2}{*}{ Cinsiyet } & Erkek & 357 & $48.9 \%$ \\
\hline & Kadın & 373 & $51.1 \%$ \\
\hline \multirow{6}{*}{ Yaş Grubu } & $18-24$ & 648 & $88.8 \%$ \\
\hline & $25-34$ & 52 & $7.1 \%$ \\
\hline & $35-44$ & 26 & $3.6 \%$ \\
\hline & $45-54$ & 4 & $0.5 \%$ \\
\hline & $55-64$ & 0 & $0 \%$ \\
\hline & $65+$ & 0 & $0 \%$ \\
\hline \multirow{5}{*}{ Kalınan Yer } & Yurt (yerleşke içi) & 286 & $39.2 \%$ \\
\hline & Yurt (yerleşke dıșı) & 160 & $21.9 \%$ \\
\hline & Konuk evi (yerleşke içi) & 1 & $0.13 \%$ \\
\hline & Ev & 281 & $38.5 \%$ \\
\hline & Diğer & 2 & $0.27 \%$ \\
\hline \multirow{6}{*}{$\begin{array}{c}\text { Alanı } \\
\text { Kullanım } \\
\text { Süresi }\end{array}$} & Günlük en fazla 1 saat & 184 & $25.2 \%$ \\
\hline & Günlük 2 saat & 218 & $29.9 \%$ \\
\hline & Günlük 3 saat & 139 & $19 \%$ \\
\hline & Günlük 4 saat & 127 & $17.4 \%$ \\
\hline & Günlük 5-9 saat & 50 & $6.9 \%$ \\
\hline & Günlük 10 saatten fazla & 12 & $1.6 \%$ \\
\hline
\end{tabular}

Görüşme yapılan yerleşke kullanıcılarına yerleşke alanının ekonomik çekiciliği, sosyal çekiciliği, ekolojik ve kültürel önemi ana başlıkları altında çeşitli sorular yöneltilmiştir. Tablo 4'te kullanıcılara yerleşkenin ekonomik çekiciliği ile ilgili yöneltilen sorular ve bu sorulara verilen cevapların fakülte birimi bazında ortalama sonuçları yer almaktadır. Tablo 4'te her bir fakülte kullanıcısının sorulara vermiş olduğu cevapların likert ölçeğine göre puan karşılı̆g belirtilmiş olup toplam puan sütunu fakültedeki toplam memnuniyet seviyesini ortaya koymaktadır.

Ekonomik açıdan çekicilik: i) Yerleşke alanı içerisinde yol bulma ve mekanı algılamada zorluk yaşıyor musunuz? ii) Yerleşke alanının büyüklüğü sizce yeterli mi? iii) Çalıştığınız/Eğitim aldığınız birimin otopark alanlarından memnun musunuz? iv) Yerleşke alanındaki otopark alanlarından memnun musunuz? v) Yerleşke alanı içerisinde konumundan memnun olmadığınız alan var mı? soruları doğrultusunda değerlendirilmiştir. Buna göre; "ekonomik çekicilik" özelliği açısından yerleşke kullanıcılarının tamamının memnuniyet seviyelerinin ortalaması \% 50'dir.

Yerleşke kullanıcılarının değerlendirmelerine göre ekonomik çekicilik açısından İletişim Fakültesi, Mühendislik Mimarlık Fakültesi, Fen Bilimleri ve Sosyal Bilimler Enstitüsü birimlerinin az çekici ve en düşük memnuniyet seviyesine sahip mekanlar olduğu, Fen-Edebiyat Fakültesi, İktisadi ve İdari Bilimler Fakültesi, Sosyal Bilimler Enstitüsü, Rektörlük Binası ve Kütüphane Binası en çekici, dolayısıyla en yüksek memnuniyet seviyesine sahip mekanlar olduğu sonucu ortaya çıkmaktadır (bkz. Tablo 4). Bu birim kullanıcılarının en yüksek memnuniyet seviyesinde yer almalarının, Tablo 1' de belirtilen matristeki "akıllı yer seçimi", "erişilebilirlik" ve bunlara bağlı olarak "cazibe merkezi” olma gibi özelliklerin, kullanıcısı oldukları birimlerde bulunmasından kaynaklandığı görülmektedir. 
Tablo 4. Erdoğan Akdağ Yerleşkesi'nin Ekonomik Çekicilik Açısından Değerlendirilmesi

\begin{tabular}{|c|c|c|c|c|c|c|c|c|}
\hline Ortalama & 1 & 3.50 & 3.50 & 3 & 3.02 & & & \\
\hline Tepedeğer & 1 & 5 & 5 & 5 & 2.92 & & & \\
\hline Standart Sapma & 0 & 2 & 2 & 2.10 & 0.30 & & & \\
\hline Standart Hata & 0 & 0.50 & 0.50 & 0.50 & 0.10 & & & \\
\hline Birim Adı & 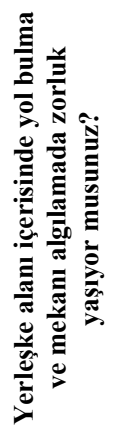 & 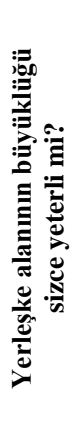 & 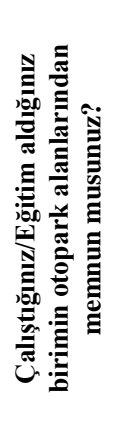 & 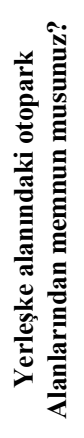 & 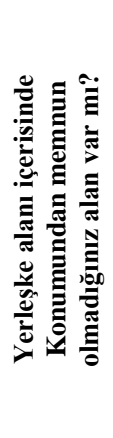 & 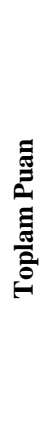 & 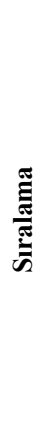 & 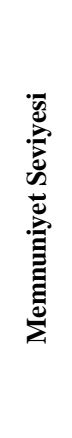 \\
\hline Eğitim Fakültesi & 1 & 1 & 5 & 5 & 1 & 13 & 7 & $52 \%$ \\
\hline Fen Edebiyat Fakültesi & 1 & 5 & 5 & 5 & 1 & 17 & 1 & $68 \%$ \\
\hline $\begin{array}{l}\text { İktisadi ve İdari Bilimler } \\
\text { Fakültesi }\end{array}$ & 1 & 5 & 5 & 5 & 1 & 17 & 1 & $68 \%$ \\
\hline İlahiyat Fakültesi & 1 & 1 & 1 & 1 & 1 & 5 & 15 & $20 \%$ \\
\hline İletişim Fakültesi & 1 & 5 & 1 & 1 & 1 & 9 & 11 & $36 \%$ \\
\hline $\begin{array}{l}\text { Mühendislik Mimarlık } \\
\text { Fakültesi }\end{array}$ & 1 & 5 & 1 & 1 & 1 & 9 & 11 & $36 \%$ \\
\hline Tip Fakültesi & 1 & 5 & 5 & 5 & 1 & 17 & 1 & $68 \%$ \\
\hline Ziraat Fakültesi & 1 & 1 & 5 & 5 & 1 & 13 & 7 & $52 \%$ \\
\hline Beden Eğitimi Yüksekokulu & 1 & 1 & 1 & 1 & 1 & 5 & 15 & $20 \%$ \\
\hline Sağlık Yüksekokulu & 1 & 1 & 5 & 1 & 5 & 13 & 7 & $52 \%$ \\
\hline Sağlık Hizmetleri MYO & 1 & 5 & 5 & 1 & 1 & 13 & 7 & $52 \%$ \\
\hline Fen Bilimleri Enstitüsü & 1 & 5 & 1 & 1 & 1 & 9 & 11 & $36 \%$ \\
\hline Sağlık Bilimleri Enstitüsü & 1 & 5 & 1 & 1 & 1 & 9 & 11 & $36 \%$ \\
\hline Sosyal Bilimler Enstitüsü & 1 & 1 & 5 & 5 & 5 & 17 & 1 & $68 \%$ \\
\hline Kütüphane & 1 & 5 & 5 & 5 & 1 & 17 & 1 & $68 \%$ \\
\hline Rektörlük & 1 & 5 & 5 & 5 & 1 & 17 & 1 & $68 \%$ \\
\hline
\end{tabular}


Yerleşke morfolojik olarak incelendiğinde ekonomik çekicilik açısından en yüksek değere sahip olan birimlerin tamamının erişilebilirliği en yüksek alanlarda bulunduğu ve bu alanlara gerek yaya olarak gerekse taşıt kullanarak rahatlıkla erişim sağlanabileceği, taşıt kullanıcıları için ayrıca herhangi bir otopark alanı sıkıntısının yaşanmayacağı görülmektedir (bkz. Şekil 2).

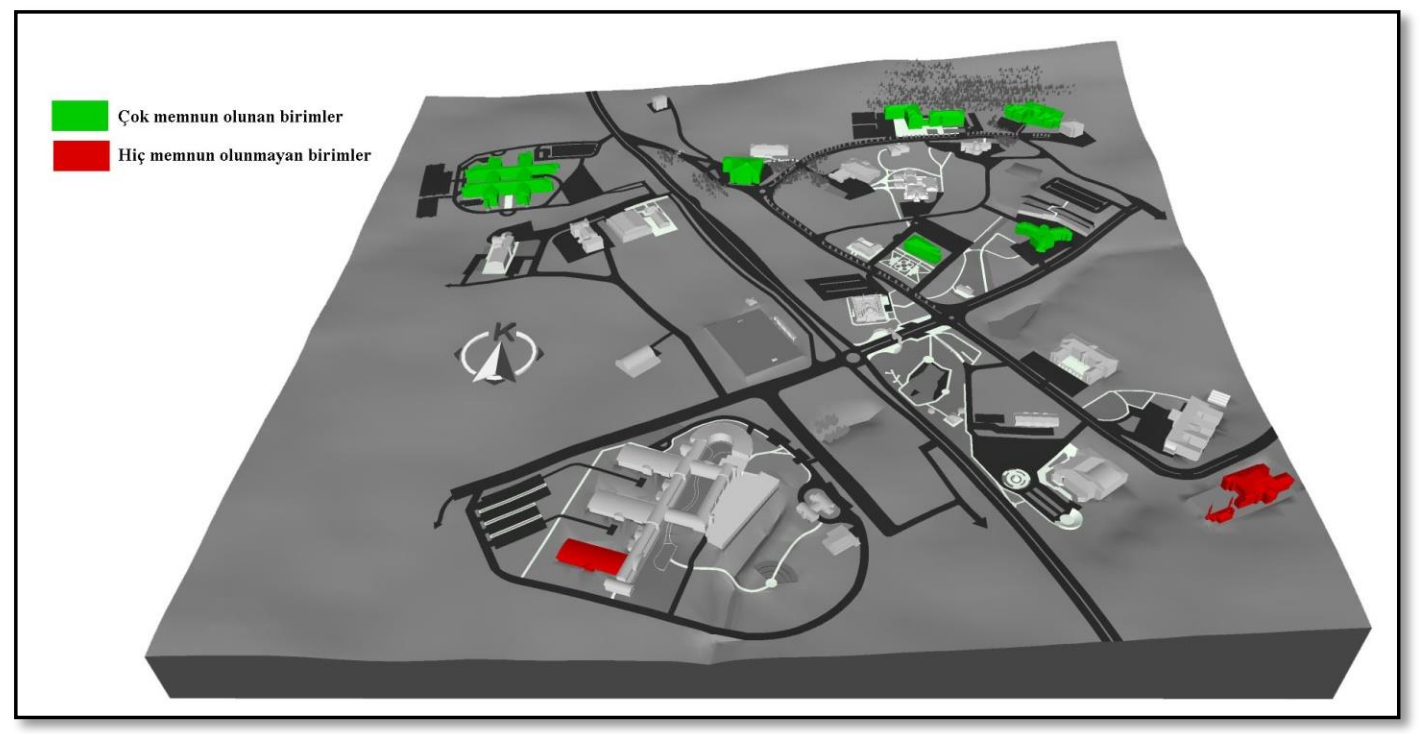

Şekil 2. Yerleşke Alanından Ekonomik Çekicilik Özelliğine Göre Memnun Olunan ve Olunmayan Birimler

Tablo 4'te yerleşke alanında ekonomik çekicilik özelliği açısından hiç memnun olunmayan birimlerin ise İlahiyat Fakültesi ve Beden Eğitimi Yüksekokulu olduğu görülmektedir. İlahiyat Fakültesi ve Beden Eğitimi Yüksekokulu'nun yerleşke alanının görece daha çeper kısımlarında yer alması ve buna bağlı olarak erişilebilirlik ve cazibe olanaklarının düşük olmasının, bu birim kullanıcılarının en düşük memnuniyet seviyesine sahip olmalarındaki temel neden olduğu söylenebilir.

Bunlara ek olarak kullanıcılara yöneltilen "Yerleşke alanı içerisinde konumundan memnun olmadığınız bina var $m \imath$ ?" sorusuna verilen ikincil cevaplarda konumundan memnun olunmayan yapıların \% 50 memnuniyet seviyesi ile Çarşı Binası, \% 37,5 memnuniyet seviyesi ile otobüs durakları ve \% 31,3 memnuniyet seviyesi ile Yemekhane Binası olduğu görülmektedir.

Yerleşke alanının sosyal çekicilik açısından genel durumu Tablo 5'te yer almaktadır. Tablo 5'te kullanıcılara yerleşkenin sosyal çekiciliği ile ilgili yöneltilen sorular ve bu sorulara verilen cevapların fakülte birimi bazındaki ortalama sonuçları yer almaktadır.

Sosyal açıdan çekicilik: i) Yerleşke alanı içerisinde özgün, göze hoş gelen yapı ya da alan bulunuyor mu? ii) Yerleşke alanı içerisinde kendinizi oraya ait hissettiğiniz bina ya da mekan bulunuyor mu? iii) Yerleşke alanı içerisinde zorunluluk olmadan sürekli kullanmak istediğiniz bina ya da alan bulunuyor mu? iv) Yerleşke alanı içerisinde eğitim öğretim saatleri dışında, ya da hafta sonları kullandığınız mekan var mıdır? v) Yerleşke alanı içerisinde yürümekten zevk aldığınız yürüme alanları var mıdır? vi) Yerleşke alanı içerisinde kolay yol bulma ve mekanı algılamada zorluk yaşıyor musunuz? vii) Yerleşke alanı içerisinde sosyalleşme imkanı sağladığını düşündüğünüz mekanlar var mıdır? soruları doğrultusunda belirlenmiş olup, bu sorular "seçim alternatifleri”, "bağlantılılık" ve "sosyal güvenlik" öğeleri kapsamında oluşturulmuştur (bkz. Tablo 5). 
Tablo 5. Erdoğan Akdağ Yerleşkesinin Sosyal Çekicilik Açısından Değerlendirilmesi

\begin{tabular}{|c|c|c|c|c|c|c|c|c|c|c|}
\hline Ortalama & 3 & 1.50 & 1 & 1 & 1.50 & 1 & 1.75 & & & \\
\hline Tepedeğer & 5 & 1 & 1 & 1 & 1 & 1 & 1 & & & \\
\hline Standart Sapma & 2.1 & 1.4 & 0.0 & 0.0 & 1.4 & 0.0 & 1.6 & & & \\
\hline Standart Hata & 0.5 & 0.3 & 0.0 & 0.0 & 0.3 & 0.0 & 0.4 & & & \\
\hline Birim Adı & 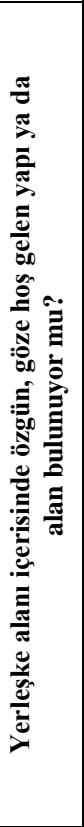 & 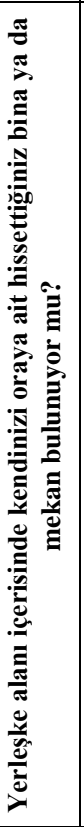 & 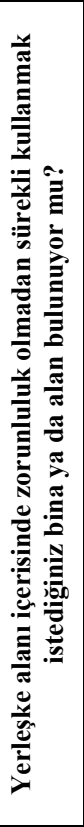 & 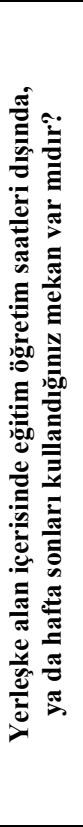 &  & 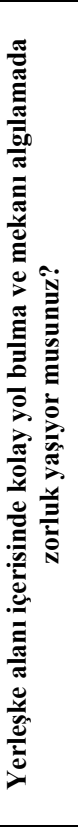 & 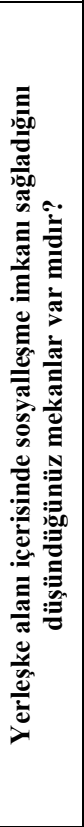 & 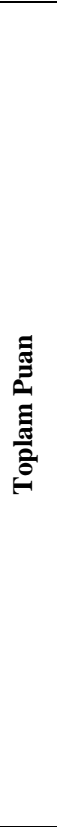 & 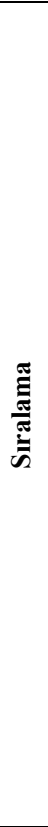 & 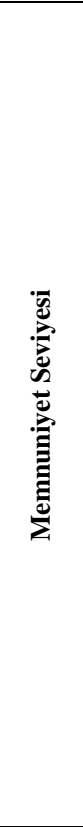 \\
\hline Eğitim Fakültesi & 5 & 1 & 1 & 1 & 1 & 1 & 1 & 11 & 4 & $31.4 \%$ \\
\hline Fen Edebiyat Fakültesi & 5 & 1 & 1 & 1 & 1 & 1 & 1 & 11 & 4 & $31.4 \%$ \\
\hline $\begin{array}{l}\text { İktisadi ve İdari Bilimler } \\
\text { Fakültesi }\end{array}$ & 1 & 1 & 1 & 1 & 1 & 1 & 1 & 7 & 9 & $20 \%$ \\
\hline İlahiyat Fakültesi & 5 & 1 & 1 & 1 & 1 & 1 & 5 & 15 & 3 & $42.9 \%$ \\
\hline İletişim Fakültesi & 5 & 1 & 1 & 1 & 1 & 1 & 1 & 11 & 4 & $31.4 \%$ \\
\hline Mühendislik Mimarlık Fakültesi & 1 & 1 & 1 & 1 & 1 & 1 & 1 & 7 & 9 & $20 \%$ \\
\hline Tıp Fakültesi & 1 & 1 & 1 & 1 & 1 & 1 & 1 & 7 & 9 & $20 \%$ \\
\hline Ziraat Fakültesi & 5 & 1 & 1 & 1 & 1 & 1 & 1 & 11 & 4 & $31.4 \%$ \\
\hline Beden Eğitimi Yüksekokulu & 1 & 1 & 1 & 1 & 1 & 1 & 1 & 7 & 9 & $20 \%$ \\
\hline Sağlık Yüksekokulu & 1 & 1 & 1 & 1 & 1 & 1 & 1 & 7 & 9 & $20 \%$ \\
\hline Sağlık Hizmetleri MYO & 1 & 1 & 1 & 1 & 1 & 1 & 1 & 7 & 9 & $20 \%$ \\
\hline Fen Bilimleri Enstitüsü & 1 & 1 & 1 & 1 & 1 & 1 & 1 & 7 & 9 & $20 \%$ \\
\hline Sağlık Bilimleri Enstitüsü & 1 & 1 & 1 & 1 & 1 & 1 & 1 & 7 & 9 & $20 \%$ \\
\hline Sosyal Bilimler Enstitüsü & 5 & 1 & 1 & 1 & 1 & 1 & 1 & 11 & 4 & $31.4 \%$ \\
\hline Kütüphane & 5 & 5 & 1 & 1 & 5 & 1 & 5 & 23 & 1 & $65.7 \%$ \\
\hline Rektörlük & 5 & 5 & 1 & 1 & 5 & 1 & 5 & 23 & 1 & $65.7 \%$ \\
\hline
\end{tabular}

Tablo 5 incelendiğinde "sosyal çekicilik” özelliği açısından yerleşke kullanıcılarının tamamının memnuniyet seviyelerinin ortalaması \% 30.71'dir. Sosyal çekicilik özelliği açısından yerleşke alanından en memnun olan birimler, Kütüphane ve Rektörlük birimleridir. Bu birimlerin en yüksek memnuniyet seviyesine sahip olmalarının temel nedenleri arasında; bu birimlerin üniversitenin idari birimleri olması, kullanıcıların bu birimleri yalnızca mesai saatleri içinde kullanması ve bu birimlerin dışındaki birimlerle 
neredeyse hiç ilişki içerisinde olmamaları, Rektörlük biriminde, sosyal alan ihtiyaçları görece yüksek olan öğrencilerin bulunmaması, dolayısıyla bu birimlerdeki kullanıcıların sosyalleşme ihtiyaçlarını karşılayacak alanlara ihtiyaç duymamaları vb. etkenlerin yer aldığı söylenebilir.

Öte yandan sosyal çekicilik özelliği açısından yerleşke alanından en az memnun olunan birimler ise İktisadi ve İdari Bilimler Fakültesi, Mühendislik ve Mimarlık Fakültesi, Tıp Fakültesi, Beden Eğitimi Yüksekokulu, Sağlık Yüksekokulu, Sağllk Hizmetleri Meslek Yüksekokulu, Fen Bilimleri Enstitüsü ve Sağlık Bilimleri Enstitüsü'dür. Bu birimlerin sosyal çekicilik açısından en az memnuniyet duyulan birimler olmalarının temel sebeplerinin ise, ögrrenci ve akademik personel sayılarının yüksek olmasına karşın bu birimlerin yakın çevresinde dinlenme, eğlenme vb. imkan sunabilecek sosyal alanların yer almaması ve yerleşke alanı bütünündeki sosyalleşme alanlarının hem nicelik hem de nitelik açısından yeterli olmaması söylenebilir.

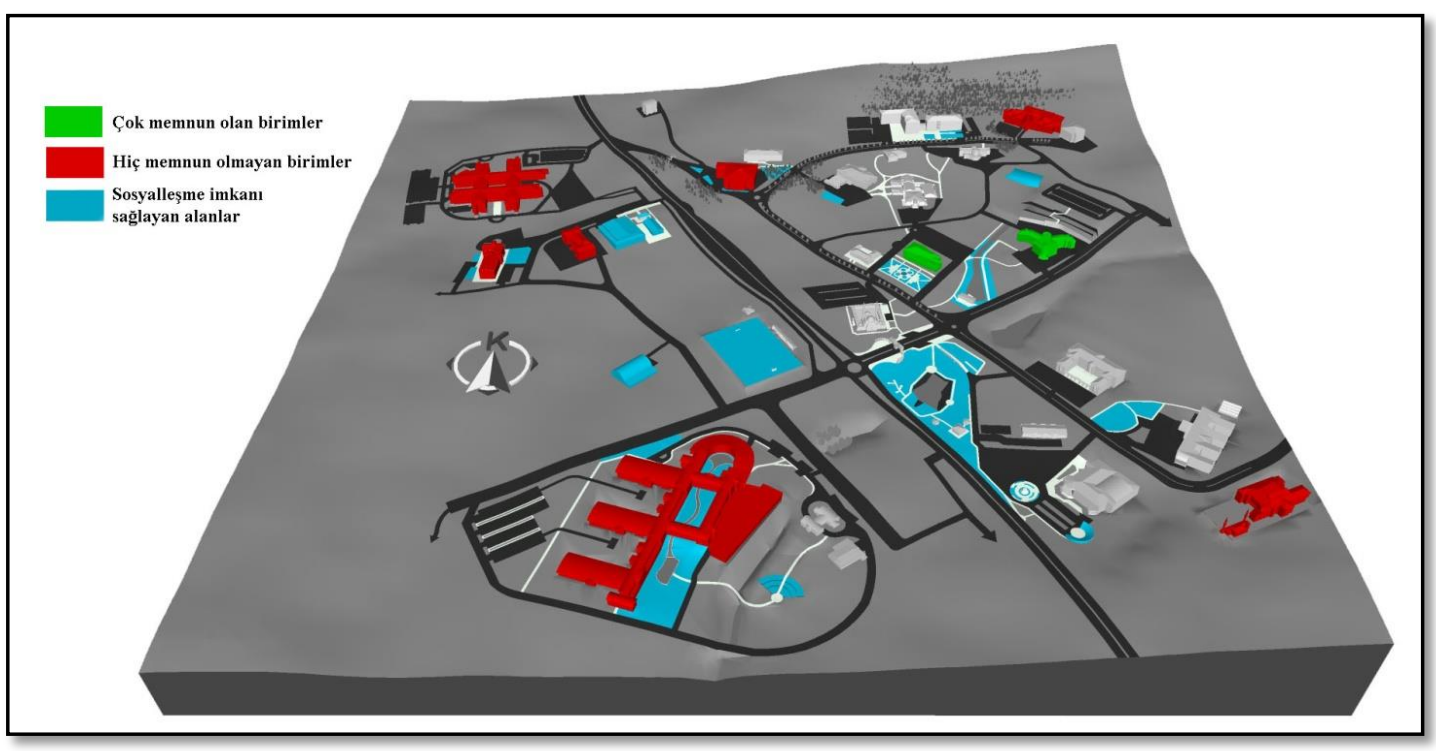

Şekil 3. Yerleşke Alanından Sosyal Çekicilik Özelliğine Göre Memnun Olan ve Olmayan Birimler

Yerleşke alanı ekolojik önem açısından genel durumu Tablo 6'da yer almaktadır. Tablo 6'da kullanıcılara yerleşkenin sosyal çekiciliği ile ilgili yöneltilen sorular ve bu sorulara verilen cevapların fakülte birimi bazında ortaya çıkan ortalama sonuçları yer almaktadır.

Yerleşke kullanıcılarına ekolojik önem açısından değerlendirme yapılabilmesi için: i) Yerleşke alanı içerisindeki açık yeşil alanların ve dinlenme alanlarının (kamelya, oturma alanları vb.) yeterliliğinden memnun musunuz? ii) Yerleşke alanı içerisinde kullanılan bank, oturma elemanı, kamelya, çöp kutusu, aydınlatma direkleri vb. elemanlardan yararlanıyor musunuz? iii? iii) Yerleşke alanı içerisinde kullanılan bank, oturma elemanı, kamelya, çöp kutusu, aydınlatma direkleri vb. elemanlarını yeterli buluyor musunuz? iv) Yerleşke alanının doğa ile ilişkisi sizce yeterli mi? v) Yerleşke alanı içerisinde kullandığınız mekanların iklimsel şartlara karşı önlemli olduğunu düşünüyor musunuz? soruları yöneltilmiştir (bkz. Tablo 6). 
Tablo 6. Erdoğan Akdağ Yerleşkesi’nin Ekolojik Önem Açısından Değerlendirilmesi

\begin{tabular}{|c|c|c|c|c|c|c|c|c|}
\hline Ortalama & 2.19 & 4.75 & 2.44 & 2.31 & 3.50 & & & \\
\hline Tepedeğer & 2 & 5 & 2 & 2 & 5 & & & \\
\hline Standart Sapma & 0.8 & 1.0 & 1.0 & 0.9 & 2.0 & & & \\
\hline Standart Hata & 0.2 & 0.3 & 0.2 & 0.2 & 0.5 & & & \\
\hline Birim Adı & 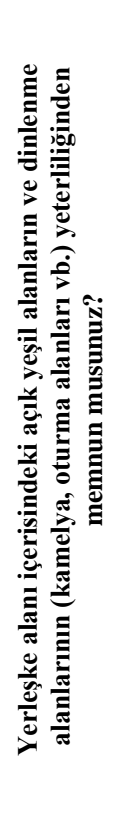 & 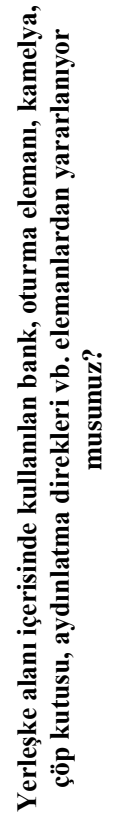 & 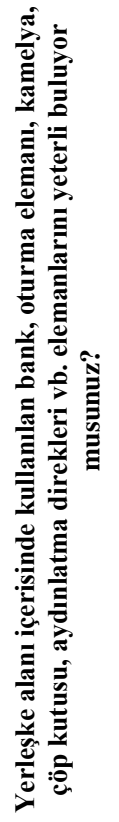 & 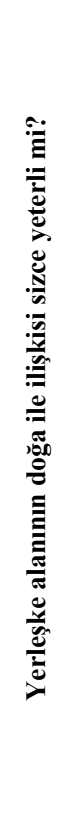 & 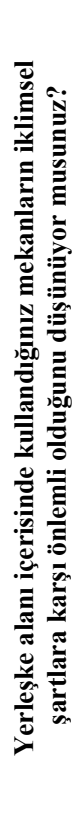 & 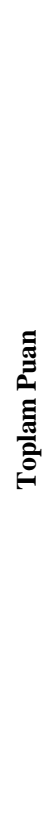 & 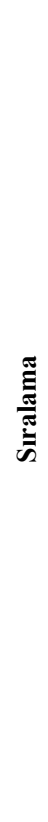 & 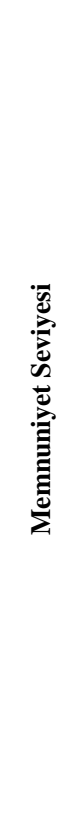 \\
\hline Eğitim Fakültesi & 2 & 5 & 2 & 2 & 1 & 12 & 11 & $48 \%$ \\
\hline Fen Edebiyat Fakültesi & 2 & 5 & 2 & 2 & 5 & 16 & 4 & $64 \%$ \\
\hline $\begin{array}{l}\text { İktisadi ve İdari Bilimler } \\
\text { Fakültesi }\end{array}$ & 2 & 5 & 4 & 2 & 5 & 18 & 3 & $72 \%$ \\
\hline İlahiyat Fakültesi & 2 & 5 & 2 & 2 & 1 & 12 & 11 & $48 \%$ \\
\hline İletişim Fakültesi & 2 & 5 & 2 & 2 & 5 & 16 & 4 & $64 \%$ \\
\hline $\begin{array}{l}\text { Mühendislik Mimarlık } \\
\text { Fakültesi }\end{array}$ & 2 & 5 & 2 & 2 & 5 & 16 & 4 & $64 \%$ \\
\hline Tip Fakültesi & 2 & 5 & 2 & 2 & 5 & 16 & 4 & $64 \%$ \\
\hline Ziraat Fakültesi & 2 & 5 & 2 & 2 & 1 & 12 & 11 & $48 \%$ \\
\hline Beden Eğitimi Yüksekokulu & 2 & 5 & 2 & 2 & 1 & 12 & 11 & $48 \%$ \\
\hline Sağlık Yüksekokulu & 1 & 5 & 1 & 1 & 1 & 9 & 16 & $36 \%$ \\
\hline Sağlık Hizmetleri MYO & 2 & 5 & 2 & 2 & 5 & 16 & 4 & $64 \%$ \\
\hline Fen Bilimleri Enstitüsü & 2 & 5 & 2 & 2 & 5 & 16 & 4 & $64 \%$ \\
\hline Sağlık Bilimleri Enstitüsü & 2 & 1 & 2 & 2 & 5 & 12 & 11 & $48 \%$ \\
\hline Sosyal Bilimler Enstitüsü & 2 & 5 & 4 & 4 & 1 & 16 & 4 & $64 \%$ \\
\hline Kütüphane & 4 & 5 & 4 & 4 & 5 & 22 & 1 & $88 \%$ \\
\hline Rektörlük & 4 & 5 & 4 & 4 & 5 & 22 & 1 & $88 \%$ \\
\hline
\end{tabular}

Tablo 6 incelendiğinde "ekolojik önem" özelliği açısından yerleşke kullanıcılarının tamamının memnuniyet seviyelerinin ortalaması \% 60,75'tir. Ekolojik önem özelliği açısından yerleşke alanından en memnun olan birimler, Kütüphane ve Rektörlük birimleridir.

$\mathrm{Bu}$ birimlerin en yüksek memnuniyet seviyelerine sahip olmalarının temel nedenleri; Rektörlük Binası için, yerleşke içindeki ana idare binası olması sebebiyle Tablo 1'de yer alan "dış güvenlik" ve "temiz 
çevre" özelliklerinin korunmasına azami özenin gösteriliyor olması, Kütüphane Binası için ise, ana kullanıcılarının, binayı yalnızca mesai saatleri içinde kullanması ve yerleşkedeki diğer alanlarla neredeyse hiç ilişki içerisinde olmaması, dolayısıyla bu birimlerdeki kullanıcıların yalnızca kendi birimleri ve yakın çevresini göz önünde bulundurarak yanıt vermeleri olarak değerlendirilebilir.

Öte yandan ekolojik önem özelliği açısından yerleşke alanından, en az memnun olan birim ise Sağlık Yüksekokulu'dur. Bu birimin, en az memnuniyet seviyesinde olmasının temel sebebi ise yakın çevresinde ekolojik önemi vurgulayabilecek alanların hem nicelik hem de nitelik bakımından yetersiz olması olarak düşünülmektedir.

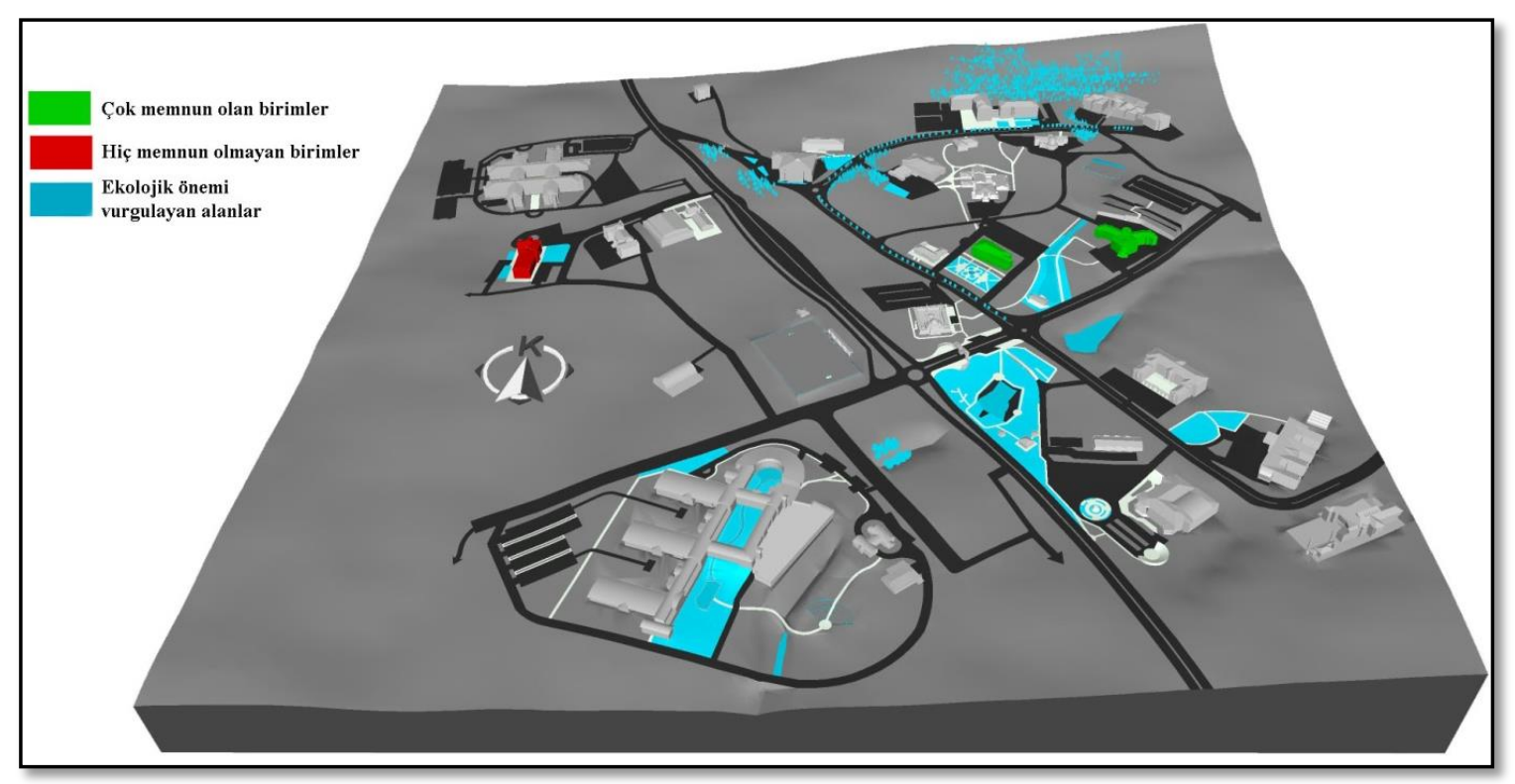

Şekil 4. Yerleşke Alanından Ekolojik Önem Özelliğine Göre Memnun Olan ve Olmayan Birimler

Yerleşke alanının kültürel önem açısından genel durumu Tablo 7'de yer almaktadır. Tablo 7'de kullanıcılara yerleşkenin sosyal çekiciliği ile ilgili yöneltilen sorular ve bu sorulara verilen cevapların fakülte birimi bazında ortalama sonuçları bulunmaktadır.

Kültürel önem açısından memnuniyet seviyeleri; i) Yerleşke alanı içerisinde özgün, göze hoş gelen yapı ya da alan bulunuyor mu? ii) Yerleşke alanı içerisinde sanatsal objelerin olmasını ister misiniz? soruları doğrultusunda belirlenmiş̧ir (bkz. Tablo 7). 
Tablo 7. Erdoğan Akdağ Yerleşkesi’nin Kültürel Önem Açısından Değerlendirilmesi

\begin{tabular}{|c|c|c|c|c|c|}
\hline Ortalama & 3 & 4.75 & & & \\
\hline Tepedeğer & 5 & 5 & & & \\
\hline Standart Sapma & 2.1 & 1.0 & & & \\
\hline Standart Hata & 0.5 & 0.3 & & & \\
\hline Birim Adı & 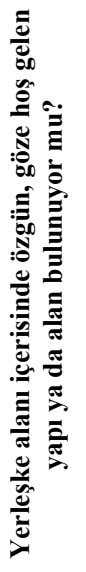 & 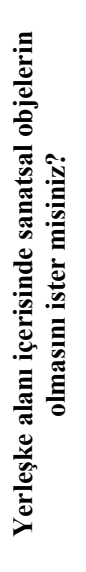 &  & 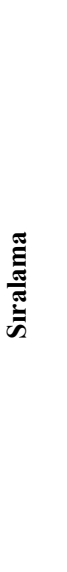 & 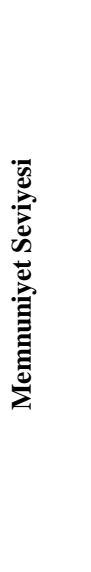 \\
\hline Eğitim Fakültesi & 5 & 5 & 10 & 1 & $100 \%$ \\
\hline Fen Edebiyat Fakültesi & 5 & 5 & 10 & 1 & $100 \%$ \\
\hline $\begin{array}{l}\text { İktisadi ve İdari Bilimler } \\
\text { Fakültesi }\end{array}$ & 1 & 5 & 6 & 9 & $60 \%$ \\
\hline İlahiyat Fakültesi & 5 & 5 & 10 & 1 & $100 \%$ \\
\hline İletişim Fakültesi & 5 & 5 & 10 & 1 & $100 \%$ \\
\hline Mühendislik Mimarlık Fakültesi & 1 & 5 & 6 & 9 & $60 \%$ \\
\hline Tıp Fakültesi & 1 & 5 & 6 & 9 & $60 \%$ \\
\hline Ziraat Fakültesi & 5 & 5 & 10 & 1 & $100 \%$ \\
\hline Beden Eğitimi Yüksek Okulu & 1 & 5 & 6 & 9 & $60 \%$ \\
\hline Sağlık Yüksekokulu & 1 & 5 & 6 & 9 & $60 \%$ \\
\hline Sağlık Hizmetleri MYO & 1 & 5 & 6 & 9 & $60 \%$ \\
\hline Fen Bilimleri Enstitüsü & 1 & 5 & 6 & 9 & $60 \%$ \\
\hline Sağlık Bilimleri Enstitüsü & 1 & 5 & 6 & 9 & $60 \%$ \\
\hline Sosyal Bilimler Enstitüsü & 5 & 5 & 10 & 1 & $100 \%$ \\
\hline Kütüphane & 5 & 5 & 10 & 1 & $100 \%$ \\
\hline Rektörlük & 5 & 5 & 10 & 1 & $100 \%$ \\
\hline
\end{tabular}

Tablo 7 incelendiğinde "kültürel önem” özelliği açısından yerleşke kullanıcılarının memnuniyet seviyelerinin ortalaması \% 80’dir. Kültürel önem özelliği açısından yerleşke alanından \% 100 memnun olan birimler, Eğitim Fakültesi, Fen Edebiyat Fakültesi, İlahiyat Fakültesi, İletişim Fakültesi, Ziraat Fakültesi, Sosyal Bilimler Enstitüsü, Kütüphane ve Rektörlük olduğu görülmektedir.

Öte yandan kültürel önem özelliği açısından yerleşke alanından en az memnun olan birimler ise İktisadi ve İdari Birimler Fakültesi, Mühendislik Mimarlık Fakültesi, Tıp Fakültesi, Beden Eğitim Yüksekokulu, Sağlık Yüksekokulu, Sağlık Hizmetleri Meslek Yüksekokulu, Fen Bilimleri Enstitüsü ve Sağlık Bilimleri Enstitüsü'dür. 


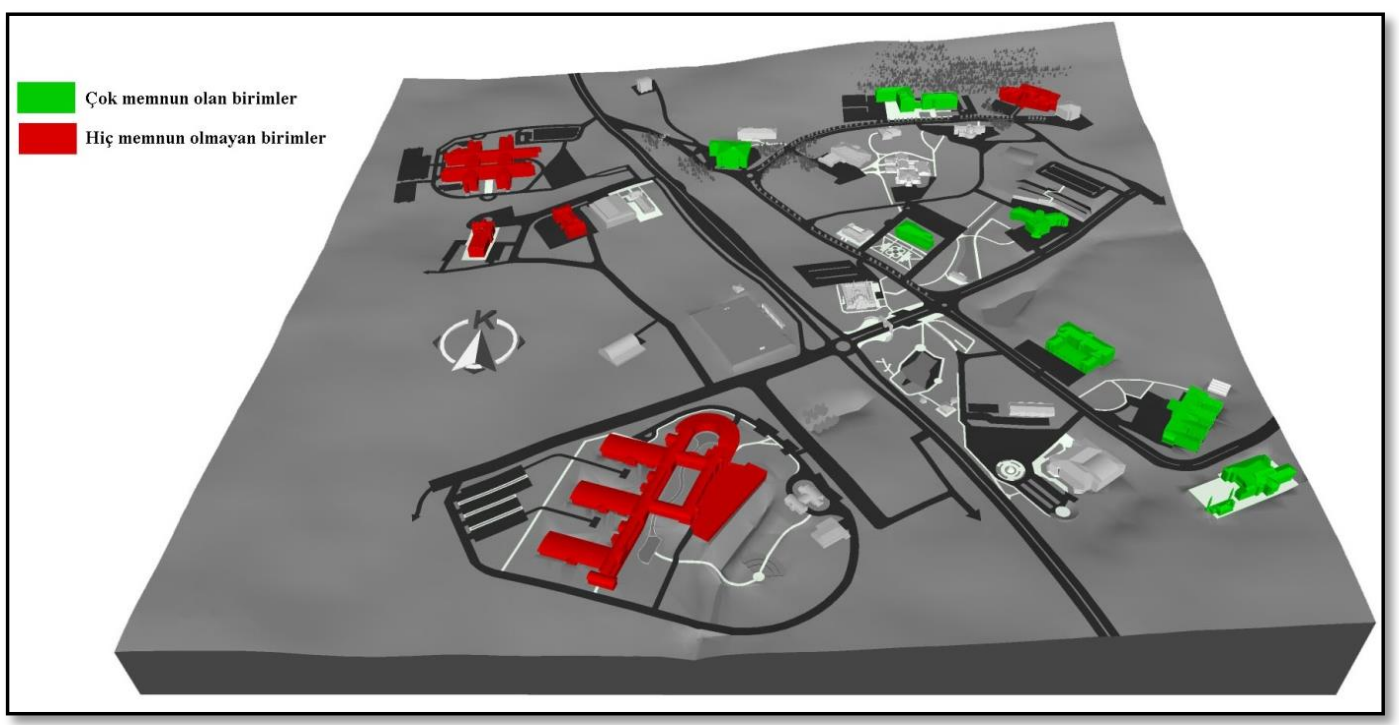

Şekil 5. Yerleşke Alanından Kültürel Önem Özelliğine Göre Memnun Olan ve Olmayan Birimler

\section{Sonuç}

Yozgat Bozok Üniversitesi kullanıcılarının yerleşke alanı bütününe ve birimlerine yönelik memnuiyet seviyelerinin değerlendirildiği bu çalışmada "ekonomik çekicilik", "sosyal çekicilik", "ekolojik önem" ve "kültürel önem" öğeleri altında yerleşke alanının yaşanılabilirlik düzeyi incelenmiştir. Yapılan anket sonuçlarına göre yerleşke mekanın sosyal çekiciliğinin düşük olduğu, bu durumun ortalama memnuniyeti de etkilediği gözlenmektedir (bkz. Tablo 8).

Tablo 8. Genel Değerlendirme

\begin{tabular}{|l|c|c|c|c|c|}
\hline Birimler/Öğeler & $\begin{array}{c}\text { Ekonomik } \\
\text { Cekicilik }\end{array}$ & $\begin{array}{c}\text { Sosyal } \\
\text { Çekicilik }\end{array}$ & $\begin{array}{c}\text { Ekolojik } \\
\text { Önem }\end{array}$ & $\begin{array}{c}\text { Kültürel } \\
\text { Onem }\end{array}$ & $\begin{array}{c}\text { Ortalama } \\
\text { Memnuniyet }\end{array}$ \\
\hline Eğitim Fakültesi & $52 \%$ & $31.4 \%$ & $48 \%$ & $100 \%$ & $57.85 \%$ \\
\hline Fen Edebiyat Fakültesi & $68 \%$ & $31.4 \%$ & $64 \%$ & $100 \%$ & $65.85 \%$ \\
\hline $\begin{array}{l}\text { İktisadi ve İdari Bilimler } \\
\text { Fakültesi }\end{array}$ & $68 \%$ & $20 \%$ & $72 \%$ & $60 \%$ & $55 \%$ \\
\hline İlahiyat Fakültesi & $20 \%$ & $42.9 \%$ & $48 \%$ & $100 \%$ & $52.73 \%$ \\
\hline İletişim Fakültesi & $36 \%$ & $31.4 \%$ & $64 \%$ & $100 \%$ & $57.85 \%$ \\
\hline $\begin{array}{l}\text { Mühendislik Mimarlık } \\
\text { Fakültesi }\end{array}$ & $36 \%$ & $20 \%$ & $64 \%$ & $60 \%$ & $45 \%$ \\
\hline Tip Fakültesi & $68 \%$ & $20 \%$ & $64 \%$ & $60 \%$ & $53 \%$ \\
\hline Ziraat Fakültesi & $52 \%$ & $31.4 \%$ & $48 \%$ & $100 \%$ & $57.85 \%$ \\
\hline Beden Eğitimi Yüksek Okulu & $20 \%$ & $20 \%$ & $48 \%$ & $60 \%$ & $37 \%$ \\
\hline Sağlık Yüksekokulu & $52 \%$ & $20 \%$ & $36 \%$ & $60 \%$ & $42 \%$ \\
\hline Sağlık Hizmetleri MYO & $52 \%$ & $20 \%$ & $64 \%$ & $60 \%$ & $49 \%$ \\
\hline Fen Bilimleri Enstitüsü & $36 \%$ & $20 \%$ & $64 \%$ & $60 \%$ & $45 \%$ \\
\hline Sağlık Bilimleri Enstitüsü & $36 \%$ & $20 \%$ & $48 \%$ & $60 \%$ & $41 \%$ \\
\hline Sosyal Bilimler Enstitüsü & $68 \%$ & $31.40 \%$ & $64 \%$ & $100 \%$ & $65.85 \%$ \\
\hline Kütüphane & $68 \%$ & $65.70 \%$ & $88 \%$ & $100 \%$ & $80.43 \%$ \\
\hline Rektörlük & $68 \%$ & $65.70 \%$ & $88 \%$ & $100 \%$ & $80.43 \%$ \\
\hline Özellik Ortalaması & $\mathbf{5 0 \%}$ & $\mathbf{3 0 . 7 1 \%}$ & $\mathbf{6 0 . 7 5 \%}$ & $\mathbf{8 0 \%}$ & $\mathbf{5 5 . 3 6 \%}$ \\
\hline
\end{tabular}


Tablo 8'e göre genel bir değerlendirme yapıldığında yerleşke bütününde ortalama memnuniyet seviyesinin \%55.36 olduğu görülmektedir. Yerleşke, bu seviyenin belirlenmesinde temel alınan habiforum matrisindeki ekonomik çekicilik, sosyal çekicilik, ekolojik önem ve kültürel önem kriterlerine göre değerlendirilirse, kullanıcılarının memnuniyet seviyelerinin en düşükten en yükseğe doğru sırasıyla sosyal çekicilik, ekonomik çekicilik, ekolojik önem ve kültürel önem olduğu görülmektedir.

Bir başka deyişle yerleşke alanı bütününde kullanıcı beklentilerini daha etkin biçimde karşılayıp, memnuniyet seviyelerini yükseltmek için oluşturulacak olası bir gelişim planında müdahale önceliği ya da ağırlığı aşağıdaki gibi olmalıdır.

Sosyal çekicilik seviyesinin artırılmasına yönelik çalışmalar yapılmalıdır. Bunlar:

$\checkmark$ Yerleşke içi ve yerleşkeye olan erişim imkanlarının gerek yaya, gerek toplu taşıma, gerekse bireysel otomobil kullanımı için artırılması,

$\checkmark$ Yerleşke alanı bütününde sosyalleşmeye olanak sağlayan alanların adil dağılımlarının sağlanması,

$\checkmark$ Yerleşke alanı bütününde farklı sosyal aktivitelere olanak sağlayan alanların oluşturulması,

$\checkmark$ Yerleşke alanı bütününde sosyalleşmeye olanak sağlayan alanların birbirleri ile ilişki içinde olmasının sağlanması,

$\checkmark$ Yerleşke alanındaki sosyalleşmeye olanak sağlayan alanların gerek kent halkının, gerekse yerleşke kullanıcılarının her daim kullanabilmelerinin sağlanması,

$\checkmark$ Yerleşke alanını kullananların, alanın tamamında kendilerini güvende hissetmelerinin sağlanması, hedeflerini içermelidir.

Ekonomik çekiciliğin artırılmasına yönelik çalışmalar yapılmalıdır. Bu çalışmalar:

$\checkmark$ Yerleşke alanı içerisindeki mevcut ve planlanan yapıların yer seçimlerinin daha akılcı ve stratejik biçimde yapılması,

$\checkmark \quad$ Yapıların ya da mekanların erişilebilirlik imkanlarının değerlendirilmesi,

$\checkmark$ Yerleşke alanı içerisinde özellikle ticari amaçlı kullanımların yer seçimi açısından gerek kullanıcılar gerekse mekanı kiralayanlar için cazip olmasının sağlanması,

$\checkmark$ Yerleşke alanı içerisindeki mevcut ve planlanan yapıların farklı amaçlar için kullanıma müsaade eder (esnek) nitelikte olmalarının sağlanması, hedeflerine uygun gerçekleştirilmelidir.

Ekolojik yapının ve öneminin vurgulanmasına yönelik çalışmalar yapılmalıdır. Bunlar:

$\checkmark \quad$ Yerleşke alanı bütününde doğal ve yapay (bina, mekan vs.) ortamların birbirlerini tamamlayıcı nitelikte olmalarının sağlanması,

$\checkmark$ Ekolojik sürdürülebilirliğin sağlanabilmesi için yerleşke alanının her daim temiz kalmasının sağlanması,

$\checkmark$ Yerleşke alanının ekolojik özellik açısından gerek kent halkı, gerekse yerleşke kullanıcıları için sağlıklı yaşam alanı niteliğine sahip olmasının sağlanması,

$\checkmark$ Yerleşke alanının yalnızca hem insanlar hem de diğer canlılar için yaşam ortamı olmasını sağlayacak düzenlemeler içermesinin sağlanması, hedeflerini kapsamalıdır.

Kültürel değerlerin sergilenmesi ve vurgulanmasına yönelik çalışmalar yapılmalıdır. Bunlar.

$\checkmark \quad$ Yerleşke alanı içerisinde kültürel mirası yaşatacak öğelere yer verilmesi,

$\checkmark$ Yerleşke alanı içerisinde kültürel faaliyetlerin gerçekleşmesine imkan sunacak organizasyonlara yer verilmesi, hedeflerini içermelidir.

$\mathrm{Bu}$ hedeflerin yürütülmesinin yerleşke alanının mekansal kalitesini artıracağı, kullanıcıların kültürel, eğitsel, sosyal ve sanatsal bilgi birikimlerini daha rahat biçimde paylaşmalarına olanak sağlayacağı, tüm bunlara bağlı olarak toplam memnuniyet seviyesini yükselteceği, aynı zamanda fiziksel mekan kalitesindeki artışın, hem eğitim öğretim kalitesinde hem de tercih edilme seviyesinde yükselişleri tetikleyeceği sonuçlarına varılmıştır.

Bilgi:

Bu çalışma, Yozgat Bozok Üniversitesi’nde Dr. Öğr. Üyesi Seçil Gül MEYDAN YILDIZ, Öğr. Gör. İlker ATMACA ve Arş. Gör. Muhammed Özgür OĞUZ tarafindan yürütülen 6602a-MMF/18-182 kodlu "Bozok Üniversitesi Erdoğan Akdağ Yerleşkesi Kullanıcılarının Mekansal Memnuniyet ve Beklenti Analizi” başlıklı Bilimsel Araştırma Projesi’nin sonuçlarını içermektedir.

\section{Kaynakça}

Aydıner Boylu, A. ve Paçacıŏlu, B. (2016). "Yaşam Kalitesi ve Göstergeleri”. Akademik Araştırmalar ve Çalışmalar Dergisi, 8 (15): 137-150. 
Evans, D.R. (1994). "Enhancing Quality of Life in Population at Large". Social lndicators Research, KluwerAcademic Publishers, 33: 47-88.

Geray, C. (2018). "Kentsel Yaşam Kalitesi ve Belediyeler". Kent, Yerel Yönetimler ve Toplu Konut Yazıları Prof. Dr. Cevat Geray. (Ed. Hasan Hüseyin Doğan), s. 283-301, Ankara: Palme Yayınevi.

İnceoğlu, M ve Aytuğ, A. (2009). "Kentsel Mekanda Kalite Kavramı". MEGARON. 4(3): 131-146, (Web: https://www.journalagent.com/megaron/pdfs/MEGARON_4_3_131_146.pdf, Erişim Tarihi: 01.10.2018).

Kabadayı, H. (2006). Yasam Kalitesi ve Kullanıcı Memnuniyetinin Kentsel Tasarımdaki Etkisine Çok Boyutlu Yaklaşım. (Yayınlanmamış Yüksek Lisans Tezi), İstanbul Teknik Üniversitesi, Fen Bilimleri Enstitüsü, Kentsel Tasarım Programı, İstanbul.

Kayır, G. Ö. (2007). Coğrafi Bilgi Sistemi’nden Yararlanarak Antalya Kenti İçin Sürdürülebilirlik Projesi. TMMOB Harita ve Kadastro Mühendisleri Odası Ulusal Coğrafi Bilgi Sistemleri Kongresi Bildiriler Kitabı. s. 561- 570, Trabzon: Karadeniz Teknik Üniversitesi Matbaası.

Okumuş, D. E. ve Eyüboğlu, E. E. (2015). "Kentsel Dönüşüm Öncesi Kentsel Yaşam Kalitesi Araştırmasına Yönelik Yöntem Önerisi ve Ataşehir Barbaros Mahallesi Örneklemi”. Planlama. 25(2): 93-106, (Web: https://www.journalagent.com/planlama/pdfs/PLAN_25_2_93_106.pdf, Erişism Tarihi: 01.10.2018).

Tekeli, İ., Güler, Ç., Vaizoglu, S., Algan, N. ve Dündar, A.K. (2004). Yaşam Kalitesi Göstergeleri, Türkiye İçin Bir Veri Sistemi Önerisi. Türkiye Bilimler Akademisi Raporları, Ankara: TÜBİTAK Matbaas1.

Topçu, K. (2011). Alışveriş Alanlarının Mekansal Kalite Açısından Değerlendirilmesi: Karşılaş̧tırmalı Bir Analiz. (Yayınlanmamış Doktora Tezi), Selçuk Üniversitesi, Fen Bilimleri Enstitüsü, Konya.

Yozgat Bozok Üniversitesi, (2019). https://bozok.edu.tr/sayfa/hakkimizda,tr-118.aspx, 26.01.2019 